\title{
Shape of skidder productivity function for ground based skidding system in Caspian forests
}

\begin{abstract}
Understanding how stand and terrain parameters impact the productivity of harvesting machines is important for determining their optimum use. Time and motion studies were conducted to evaluate the impact of terrain characteristics and work methods on skidder productivity in cut-to-length skidding system in easy and difficult terrain condition in Caspian forests. It was found that the productivity for skidding operation on selective cutting sites classified as easy and difficult terrain conditions, ranged from 18.22 to $14.25 \mathrm{~m}^{3} \mathrm{~h}-1$. The results proved that logarithmic model in both skidding distance $\left(\mathrm{R}^{2}=0.61\right.$ and $Y=-11.97 \ln (x)+78.383)$ and volume per turn $\left(R^{2}=0.53\right.$ and $\left.Y=10.058 \ln (x)+10.1580\right)$ entered in the model in easy condition. Also, the results proved that the logarithmic model in both skidding distance $\left(\mathrm{R}^{2}=0.32\right.$ and $\left.\mathrm{Y}=-6.874 \ln (\mathrm{x})+47.604\right)$ and volume per turn $\left(\mathrm{R}^{2}=0.37\right.$ and $\left.\mathrm{Y}=14.874 \ln (\mathrm{x})+1.2241\right)$ entered in the model in difficult condition. These observations suggest that maximization of payload and optimization of timber extraction distance are more crucial for economic skidding on difficult sites. Also, skidding in easy terrain condition can increase productivity until $3.97 \mathrm{~m}^{3} \mathrm{~h}^{-1}$. It can be concluded that correct design of skidding trails can resulted in more production during ground based skidding in the region.
\end{abstract}

Keywords: productivity, performance, skidding, easy, difficult condition
Volume 2 Issue I - 2018

\author{
Behjou FK \\ Department of Forestry and Forest Economics, University of \\ Mohaghegh Ardabili, Iran

\begin{abstract}
Correspondence: Farshad Keivan Behjou, Department of Forestry and Forest Economics, Faculty of Agricultural Technology and Natural Resources, University of Mohaghegh Ardabili,Ardabil, Iran, Email farshad.keivan@gmail.com
\end{abstract}

Received: August 20, 2017 | Published: January 30, 2018

\section{Introduction}

Cut-to-length (CTL) timber harvesting technology currently accounts for approximately $90 \%$ of Caspian forests. The technology involves felling, branching, cross-cutting, and then the skidder carries the logs to a landing, where the timber is temporarily stored, sorted and assembled for transportation to the mill. Cut-to-length systems typically require less labor, less access road construction, and fewer landing areas than other ground-based systems such as whole tree harvesting and also lead to more efficient wood recovery. In Caspian forests of Iran, harvesting and extraction systems are assigned to specific harvesting sites on the basis of inherent terrain class, silvicultural consideration, stand characteristics and access to the sites for the extraction of the timber. In the region, ground based kidding is the most common form of extraction of harvested timber. Forest management in Iran faces many challenges, and most forest land is governmentally held. Harvesting equipment needs to be as productive as possible. For example, efficiency of skidding operation is dependent on having a skilled operator, mechanically sound equipment and a sufficient volume of logs to be skidded. But skidding efficiency is also influence by the stand condition and harvesting prescription. Information on the productivity, cost and application of harvesting machines is a key component in the evaluation of management plans for the rehabilitation and utilization of Caspian forests. ${ }^{1}$ Logging and transporting optimization are becoming key areas for improvement. Improving operational efficiency through better management is one way that the Iranian forest industry can enhance its competitive position. Due to the higher initial cost of mechanized harvesting machines, larger diameters and crowns of hardwoods, and the relatively steep terrain in Caspian forests, Wheeled skidders is still the most commonly used machines in the region, on the other hand research efforts for modeling and planning improvements to the wood chain are increasing. Essentially, all Caspian forests in the Iran are harvested with cut-to-length system. Few previous studies addressed techno-economic analysis of skidding operation in Caspian hardwood stands under different harvest conditions. Jones et al. ${ }^{2}$ conducted a time study on a 60 -acre tract with three thinning treatments in northern West Virginia. The three treatments were defined as $45 \%, 60 \% \& 75 \%$ of the residual stocking. The harvest comprised of manual felling with a chainsaw. Time studies showed that hourly felling production increased while skidding productivity decreased from the treatments 45 percent, to 60percent, and to 75 percent of residual stocking. Regression equations were later developed based on the above timestudy data, ${ }^{3}$ which can be used for estimating production rates and costs for similar thinning operations.

Some production/cost studies using manual harvesting systems have been conducted in harvesting planted pine stands in the south. Kluender \& Stokes ${ }^{4,5}$ conducted a time study on a southern pine harvest consisting of manual felling, grapple skidding, and cable skidding. The harvest method ranged from clear cutting to single-tree selection and the proportion of basal area removed was used to measure harvest intensity. Spinelli \& Hartsough ${ }^{6}$ time studied Caterpillar 950F frontend loader and a Caterpillar 528 grapple skidder used to extract trees; they found that front-end loader is $40-60 \%$ more productive than grapple skidder. Tiernan et al. ${ }^{7}$ found that uphill extraction reduce the forwarder productivity by between 0.8 and $5.1 \mathrm{~m}^{3} / \mathrm{h}$ compared to downhill, hence, the latter should be adapted wherever it is practicable, for economic reasons. Wang et al. ${ }^{8}$ developed a productivity model for chain-saw felling, which included variables such as diameter at breast height and the distance between harvested trees. Holmes et al. ${ }^{9}$ showed that the productivity and cost of rubber tired skidder were $22.39 \mathrm{~m}^{3} / \mathrm{h}$ and US $\$ 1.99$, respectively.

This study investigated alternative methods for quantifying production function in logged forest areas for first time in Caspian forests. The objective of present study was to evaluation of the main factors affecting skidder productivity, to facilitate the development of prediction models for the estimation of their productivity on a range of different harvesting sites in Iran. 


\section{Material and methods}

\section{Site of study}

This study was carried out in compartments 237 and 238 in Shafaroud forests in the north of Iran. The altitude ranged from 1080 to $1270 \mathrm{~m}$ above sea level and the average annual precipitation is $1450 \mathrm{~mm}$. The forest was uneven-aged Fagetum (fagus orientalis Lipsky) with the average growing stock $307 \mathrm{~m}^{3} /$ ha. The slope of the compartment was 22 to $55 \%$ and the aspects of the slope were northern. The total volume of production was $1700 \mathrm{~m}^{3}$ and the skidding of production was done from the stump area to the roadside landing by ground-base skidding system. Forestry machinery used in the present study included rubber tired skidder. The skidder type used in this study was wheeled skidder Timberjack 450C, with the power of $177 \mathrm{HP}$ and the weight was $10,257 \mathrm{~kg}$. Table 1 shows the characteristics of the study area. Dominant canopy species include Fagus orientalis; Carpinus betulus; Acer velutinum, Alnus subcordata and Ulmus glabra. Canopy height averages approximately to $26 \mathrm{~m}$.

Table I characteristics of study area

\begin{tabular}{lll}
\hline Compartment 238 & Compartment 237 & Characteristics \\
\hline 72 & 47 & Area (ha) \\
1200 & 1350 & Height above sea level \\
30 & 35 & Average slope (\%) \\
northern & northern & General aspect \\
Mixed hardwood & Beech and alder & Current community \\
325 & 360 & Volume per hectare $\left(\mathrm{m}^{3}\right)$ \\
\hline
\end{tabular}

The field study was conducted in March of 2016 on Shafaroud forests, north of Iran. The operator of the Timber jack 450C both had several years experience with that type of machine.

\section{Methods}

Factors that have a major influence on the productivity of timber extraction by skidders include the payload, skidding distance in the extraction cycle, driving speed, and the terrain conditions, which restrict the attainable maximum driving speeds. The determination of the productivity of a skidder is based on the measurement of cycle time required to extract a pay load from the forest to a landing on the roadside for secondary transportation. Times and operational variables were measured using a stopwatch and recorded on paper. ${ }^{1,10}$ Time and motion studies for the skidding operations were conducted in 6 forest sites. The work cycle for each operation consisted certain elemental functions and factors (Table 2). The times for each function and the value of each factor were recorded in the field. Elemental time functions for skidding were defined as: Travel empty, establishment time, release and pulling, hook, winching, travelloaded, unhook, and pilling. Skidding factors or operational variables for ground based skidding measured in the field include number of logs per turn, skidding distance $(\mathrm{m})$, winching distance $(\mathrm{m})$, volume per turn $\left(\mathrm{m}^{3}\right)$, and ground slope (\%). A total of 2 skidders owned by Shafaroud Governmental Company were studied. In present study, terrain classification was done based on ground roughness and slope (Table 1). To evaluate the impact of terrain conditions on skidder productivity, the database was classified into two categories, namely easy and difficult terrain conditions. An easy terrain condition was defined as (Table 1) skidding on average to good ground conditions, even terrain, and ground slopes of less than $10 \%$. Difficult terrain condition was defined as skidding on poor to very poor ground conditions, uneven to rough terrain, and on slopes of greater than $10 \%$.

Table 2 Terrain classification system applied during the study

\begin{tabular}{llll}
\hline General site description & $\begin{array}{l}\text { Terrain } \\
\text { condition }\end{array}$ & Classification & \\
\hline $\begin{array}{l}\text { Obstacles of } 10-30 \mathrm{~cm} \\
\text { covering }\end{array}$ & Easy & Even & \\
$\begin{array}{l}\text { Frequent obstacles of } 30- \\
50 \mathrm{~cm} \text { covering }\end{array}$ & Difficult & Uneven & $\begin{array}{l}\text { Ground } \\
\text { roughness }\end{array}$ \\
$5-40 \mathrm{~m}^{2}$ in $100 \mathrm{~m}^{2}$ & & Rough & \\
$\begin{array}{l}\text { Obstacles }>30-50 \mathrm{~cm} \text { covering } \\
5-40 \mathrm{~m}^{2} \text { per } 100 \mathrm{~m}^{2} \text { or greater }\end{array}$ & & Gentle & \\
$0-10 \%$ & Easy & Intermediate & Slope \\
$11-20 \%$ & Difficult & Steep & \\
$21-33 \%$ & & Very steep & \\
$33 \%$ or over & & & \\
\hline
\end{tabular}

Each log was measured for $\mathrm{dbh} /$ mid diameter to the nearest centimeter. The Minitab 13.1 statistical program was used to analyze the data.

In addition to the total skidding cycle time we considered delay time. The delay times and the reasons of the delay were also recorded. Three categories of delays were used in the delay analysis as persona, mechanical, and operational delays. It was assumed that the skidding time per cycle is a function of the above mentioned variables. The stepwise regression model was applied to develop a model. In this method, if any variable has a significant effect on the RMS (Residual Mean Squares) of the model, it would be used in the model. The collected data were analyzed to (1) evaluate the variation of skidder productivity in $\mathrm{m}^{3} \mathrm{~h}$ with the volume of payload in $\mathrm{m}^{3}$ and the average extraction distance in $\mathrm{m},(2)$ compare the skidder productivity under different working conditions for the range of payload and average extraction distance, and (3) assess the significance of any other variable that could impact on skidder productivity during extraction. The statistical significance of the data for all stages was analyzed using t-test. The field data were entered in Minitab software for analysis. The data was stored according to average extraction distance, volume of payload, and machine productivity. The data were plotted and the best fitting line was determined.

Analysis of skidder productivity under easy and difficult terrain conditions were based on 18 and 38 load cycles, respectively. The related data were plotted and lines of best fit were determined. The variation of skidder productivity with volume of payload and travel distance in the transportation cycle was characterized from the experimental data by multiple non-linear regression and correlation analysis. On the basis of scatter-plots of the variation of skidder productivity with volume of timber payload $\mathrm{V}$ and extraction distance $\mathrm{d}$, the association (functional forms) that best fitted the data was determined from the general expression in the following equation, where $\mathrm{B}_{0}, \mathrm{~B}_{1}, \mathrm{~B}_{2}$, and $\mathrm{B}_{3}$ are regression coefficients.

$$
P=B_{0}+B_{1} V+B_{2} D+B_{3} \ln (D)
$$

The sensitivity of the factors that affected the skidder productivity when working in difficult terrain conditions for skidding operations 
was determined by dividing the data into three broad categories including site-related, stand-related and the working method. The site-related analysis examined the effects of ground conditions, surface roughness and slope on skidder productivity. The standrelated analysis examined the effects of assortment density on skidder productivity.

\section{Results and discussions}

\section{Skidder productivity}

It was found that the productivity for skidding operation on selective cutting sites classified as easy and difficult terrain conditions, ranged from 18.22 to $14.25 \mathrm{~m}^{3} \mathrm{~h}^{-1}$. Scatter-plots of the variation of skidder productivity with volume of payload and with average extraction distance from harvesting sites are presented in Figure $1 \&$ Figure 2 . For both sets of data, it was observed that the variation in skidder productivity was sensitive to both volume of payload and average skidding distance, which is agreement with most available literature. ${ }^{6,7}$ The measured productivity of timber skidding under the easy conditions ranged between 11 and $31 \mathrm{~m}^{3} \mathrm{~h}^{-1}$. It is shown that the variation in skidder productivity was mainly (coefficient of determination $\mathrm{R}^{2}=0.53$ ) influenced by linear component of the volume of payload. The best regression $\left(\mathrm{R}^{2}=0.61\right)$ for the variation of productivity with skidding distance was a logarithmic function (Figure1). Figure 2 shows the characteristics curves for the harvesting sites. It was observed that for each payload, the skidder productivity reduced with the average skidding distance at a rate that was independent of the volumetric payload (indicated by the parallel productivity contours). The rate of decline in productivity was higher for lower average skidding distances, and reduced from $10 \mathrm{~m}^{3} \mathrm{~h}$ to $29 \mathrm{~m}^{3} \mathrm{~h}$, at easy condition. Figure 3 shows the regression model $\left(\mathrm{R}^{2}=0.32\right)$ of skidder productivity as a function of average skidding distance for different skidder timber payload at difficult condition. It was observed that for each payload, the predicted skidder productivity declined linearly with the extraction distance. Figure 4 shows the regression model $\left(\mathrm{R}^{2}=0.37\right)$ of skidder productivity as a function of volume per turn at difficult condition. It was observed that for each payload, the predicted skidder productivity declined linearly with the extraction distance.

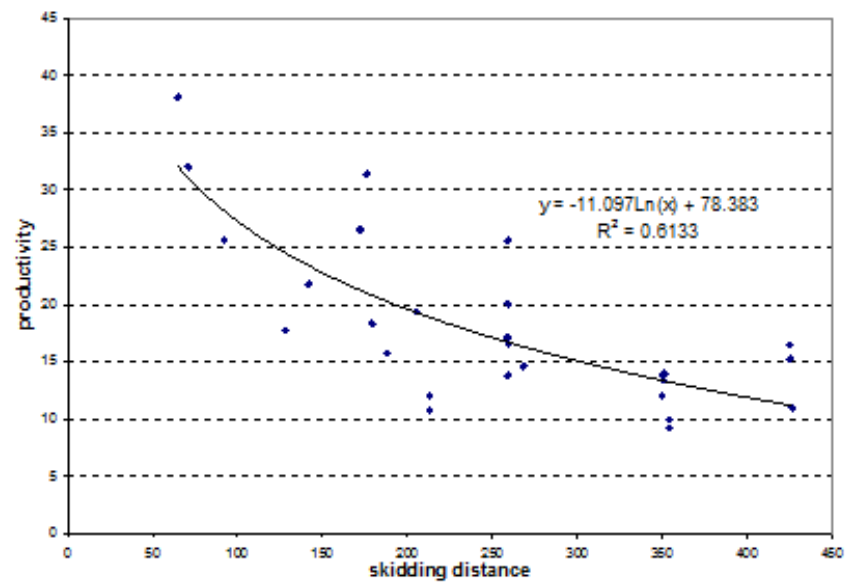

Figure I Relationship between skidder productivity $\left(\mathrm{m}^{3} / \mathrm{h}\right)$ and skidding distance $(m)$ in easy terrain condition.

\section{Skidder performance}

Results of the influence of terrain conditions (i.e. easy and difficult condition) on skidder productivity in harvesting sites for the range of payloads and average skidding distances studied on presented in Figure 1-4. Results of the regression and correlation analyses on the measured skidder productivity against the volume of skidder payload and average extraction distance are presented in Figure 1-4. It is shown that the logarithmic model in both skidding distance $\left(\mathrm{R}^{2}=0.61\right.$ and $\left.\mathrm{Y}=-11.97 \ln (\mathrm{x})+78.383\right)$ and volume per turn $\left(\mathrm{R}^{2}=0.53\right.$ and $\mathrm{Y}=10.058 \ln (\mathrm{x})+10.1580)$ entered in the model in easy condition. Also, It is shown that the logarithmic model in both skidding distance $\left(\mathrm{R}^{2}=0.32\right.$ and $\left.\mathrm{Y}=-6.874 \ln (\mathrm{x})+47.604\right)$ and volume per turn $\left(\mathrm{R}^{2}=0.37\right.$ and $\mathrm{Y}=14.874 \ln (\mathrm{x})+1.2241)$ entered in the model in difficult condition.

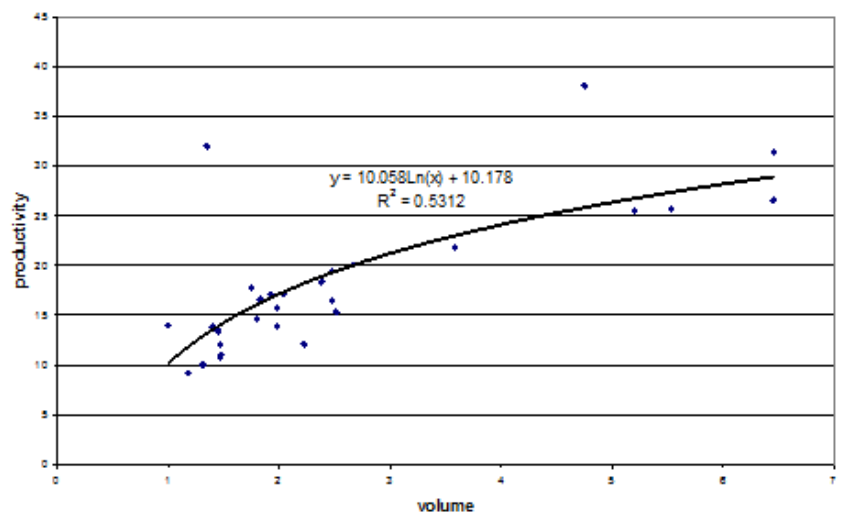

Figure 2 Relationship between skidder productivity $\left(\mathrm{m}^{3} / \mathrm{h}\right)$ and volume per turn $\left(\mathrm{m}^{3}\right)$ in easy terrain condition.

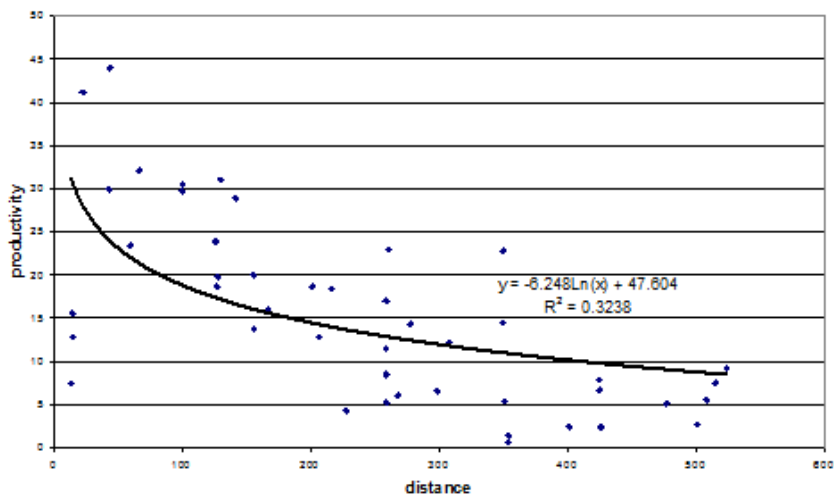

Figure 3 Relationship between skidder productivity $\left(\mathrm{m}^{3} / \mathrm{h}\right)$ and skidding distance $(m)$ in difficult terrain condition.

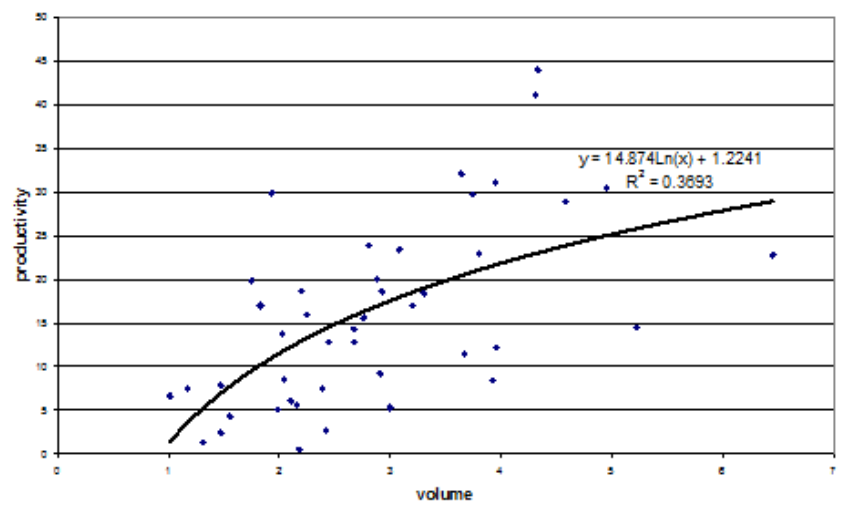

Figure 4 Relationship between skidder productivity $\left(\mathrm{m}^{3} / \mathrm{h}\right)$ and volume per turn $\left(\mathrm{m}^{3}\right)$ in difficult terrain condition. 


\section{Discussion}

Empirical models can be very useful for describing the relationship between machine performance and many different stand and terrain parameters. Mechanized skidding machines are not frequently used to feel very large timber, and in many applications the use of a simple power function will be appropriate to represent their productivity.

While the more complex exponential function better represents the data, and especially the behavior beyond the optimum, there is the risk of over-parameterization of the model. These models focus only on piece size; all other factors, such as travel time, are removed from the data sets. Using more parameters means that more data needs to be gathered to obtain model significance. The effects of branch size and tree form are also important, and have been included in other models.

Skidder productivity in cut-to-length forest harvesting system is strongly correlated to the volume of payload size and the average extraction distance, and is expected to increase with increases in payload, but decrease with the increase in average extraction distances. The following conclusions may be drawn from the results in this study:

a. In harvesting sites, skidder productivity is expected to decline with increasing the average timber extraction distance independently of the payload.

b. The predicted productivity for skidding operation on harvesting sites with easy and difficult terrain conditions ranged from 18.22 to $14.25 \mathrm{~m}^{3} \mathrm{~h}^{-1}$.

c. Compared to easy condition, difficult train condition will significantly reduce skidder productivity.

\section{Conclusion}

Empirically based productivity functions are often used to describe the performance of forestry machinery as it relates to varying stand and terrain variables. Such models can be used to compare machinery, optimize work conditions, or formulate compensation rates. This study showed that volumes per turn and skidding distance have a nonlinear effect on productivity and that this effect should be considered when analyzing empirical data or developing productivity models. It also provides more conservative estimates than alternative other models.

The variables such as skidding distance and volume per turn were entered into the general model for predicting skidding time as significant variables, which can be applied in harvesting planning. The skidding cycle time per tree and productivity were mostly affected by skidding distance but was also affected by the volume per turn. Increasing volume per turn will increase skidding time, but if extractions distance increase, the skidding time decreases. The results in this study will be helpful for the loggers in selecting an appropriate system under certain stand and harvest circumstances. Average tree volume is a crucial factor in selective logging associated with harvesting. The skidding distance is a key factor affecting the productivity in selection logging. The productivity increases with higher payload of the machine and with shorter distance. From the general scenario difference in the productivity of the different machine is few visible. Makkonen ${ }^{11}$ studied the productivity of Timber jack $230 \mathrm{~A}$ and found $24 \mathrm{~m}^{3} / \mathrm{h}$ for $360 \mathrm{~m}$ hauling distance and $31.6 \mathrm{~m}^{3} / \mathrm{h}$ for $170 \mathrm{~m}$ hauling distance. These productivities are reached by Timber jack 450C in this study. From the economic point of view the Timber jack $450 \mathrm{C}$ could be recommended for selective logging operations in Caspian forests. ${ }^{12-14}$

\section{Acknowledgments}

None.

\section{Conflict of interest}

Authors declare that there is no conflict of interest.

\section{References}

1. Behjou F, Majnounian B, Namiranian M, et al. Time study and skidding capacity of the wheeled skidder Timberjack 450C in Caspian forests. Journal of Forest Science. 2008;54(4):183-188.

2. Jones KD. Time Study Analysis of Three Thinning Treatments in Mixed Oak-Cove Hardwood Stands in Northern West Virginia. Morgantown: Master's Thesis. Division of Forestry, West Virginia University. 1983. $98 \mathrm{p}$.

3. Brock SM, Jones KD, Miller GW. Felling and skidding costs associated with thinning a commercial Appalachian hardwood stand in northern West Virginia. Northern Journal of Applied Forestry. 1986;3(4):159-163.

4. Kluender RA, BJ Stokes. Productivity and costs of three harvesting methods. Southern Journal of Applied Forestry. 1994;18(4):168-174.

5. Kluender RA, Stokes BJ. Felling and skidding productivity and harvesting cost in southern pine forest. Proceedings: Certification-Environmental implications for forestry operations. 1996;9:35-39.

6. Spinelli R, Hartsough BR. Extraction whole short rotation trees with a skidder and a front-end loader. Biomass and Bioenergy. 2001;21:425-431.

7. Tiernan D, Zelek G, Owende PMO, et al. Effect of working conditions on forwarder productivity in cut-to-length timber harvesting on sensitive forest sites in Ireland. Biosystems engineering. 2004;87(2):167-177.

8. Wang J, Charlie L, McNeel J, et al. Productivity and cost of manual felling and cable skidding in central Appalachian hardwood forests. Forest Products Journal. 2004;53(3):47-53.

9. Holmes TP, Blat GM, Zweede JC, et al. Financial and ecological indicators of reduced impact logging Performance in the eastern Amazon. Forest ecology and management. 2002;163(1-3):93-110.

10. Huyler NK, LeDoux CB. A comparison of small tractors for thinning central hardwoods. In: Proceedings of the 8th Central Hard-Wood Forest Conference. USA: University Park; 1991. p. 92-104.

11. Makkonen I. Evaluation of Timber jack 230 8-ton forwarder. Canada: Forestry engineering research institute of Canada; 1989.

12. Forestry Operations. Joint conference of Canadian Woodlands Forum. Quebec City, Canada: Canadian Pulp and Paper Association and International Union of Forest Research Org. p. 35-39.

13. Limaei SM, Lohmander P. Stumpage prices in the Iranian Caspian forests. Pakistan Journal of Biological Science. 2007;6(7):1027-1036.

14. Miyata ES. Determining fixed and operating costs of logging equipment. USA: USDA Forest Services. 1980. 